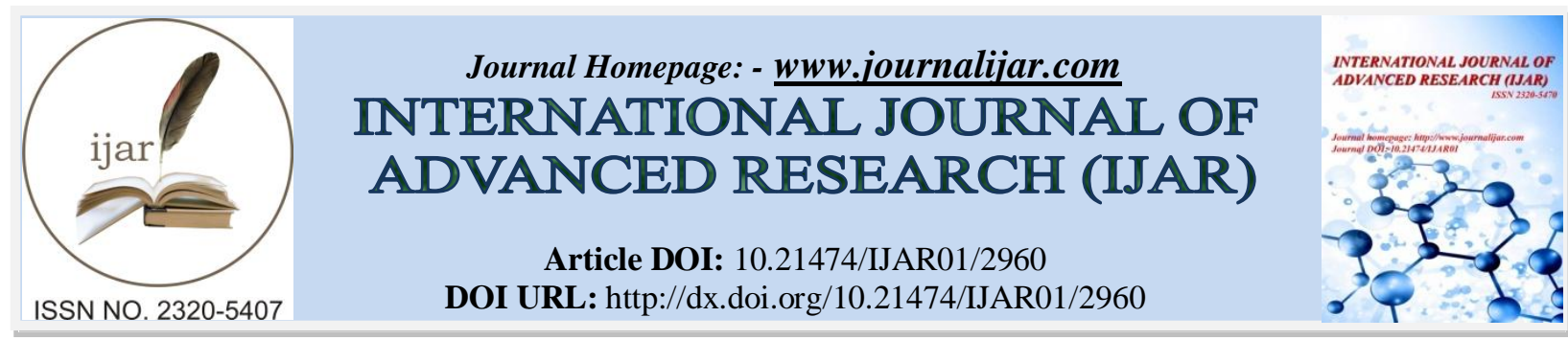

RESEARCH ARTICLE

\title{
CONTROL OF ENVIRONMENTAL POLLUTION BY EFFECTIVE UTILIZATION OF FLY-ASH PRODUCED BY THERMAL POWER PLANTS IN CULTIVATED LAND AND BIODEGRADATION OF PLASTIC USING PSEUDOMONAS SP. ISOLATED FROM WASTE WATER
}

\author{
Somnath De ${ }^{*}$, Nargis Parvin, Moumita Banerjee, Tapas Giri, Sk Iqbal Hossain, Mirza Md Mehedi Hasan and \\ Subho Panja. \\ Department of Biotechnology, Panskura Banamali College. West-Bengal. India.
}

\section{Manuscript Info \\ Manuscript History \\ Received: 30 November 2016 \\ Final Accepted: 26 December 2016 \\ Published: January 2017}

Key words:-

Biodegradation, plastics, Pseudomonas $s p$., fly-ash, seed germination and plant growth promoting activity.

\begin{abstract}
Accumulation of plastics in the environment is creating a threat to the mankind. Some plastics are degradable which do not cause threat to the environment, and are being used for several purposes such as making of containers, use for packaging, water pipes etc. In this study, the isolation and characterization of plastic degrading bacteria from paper mill waste water was done. Identification of the isolated strains was performed on the basis of colony morphology, grams nature, and several biochemical tests. Plastic strips are subjected to biodegradation by isolated bacteria using mineral salt medium. The degradation was observed by changes in physical and optical characteristics. The maximum degradation was observed in Pseudomonas sp. showed after 21 days of incubation

Utilization of fly-ash, produced by thermal power plants in different fields to control environmental pollution has given due importance for the last many years. In this paper an attempt has been made to present the results of some experiments conducted to utilize fly-ash collected from Kolaghat thermal power plant, properly by extracting its suitable nutrients, by Pseudomonas sp. isolated from waste water, useful for plant growth. To conduct this experiment, a single bacterial isolate are isolated from waste water through King's media. After single colonies isolation and thrice time purification, isolate are stored in $40 \%$ glycerol solution at isolate are separated for studying their fly-ash and their seed germination as well as plant growth promoting ability on isolate showed good results of seed treatment whether on general soil or fly have been in tabulated form.
\end{abstract}

Copy Right, IJAR, 2016,. All rights reserved.

\section{Introduction:-}

Energy is an essential ingredient for all around development of any country. In India, almost $80 \%$ of total electrical power produced, is generated by coal-based thermal power plants. Since, Indian coal consists of high percent of ash, so, when it is burnt by thermal power plants, they produce huge amount of fly-ash causing environmental pollution. With ever-increasing per capita consumption of energy due to exponentially rising population, it is not possible to reduce power generated by coal-based power plants due to environmental pollution but stress may be given to control the same. Several attempts have been made to utilize effectively this huge amount of fly-ash without

Address:- Department of Biotechnology, Panskura Banamali College. West-Bengal. India. 
dumping into the ash-pond or on the bare lands. For example: the production of in-organic polymer[1,2], production of nano-structure materials[3] and utilization in concrete and cement production is the most effective one for both economic and ecological point of view.

Plastics are the polymers which on heating become mobile and can be cast into moulds. Plastics are non-metallic compounds that can be molded into any desired shapes and sizes. Plastics are used for packaging, making diapers, fishing nets, agricultural films and also used for many more purposes. Plastics and their use has become a part in all sectors of economy. Present demand of plastics is increasing in the areas of agriculture, consumer goods, health and medicine [4]. Plastics can be categorized into some of the basics classes such as: natural plastics, semi synthetic plastics, synthetic plastics, thermoplastics, thermosetting plastics. Amongst these plastics comes the Low density polyethylene (LDPE), Medium density polyethylene (MDPE) and High density polyethylene (HDPE) products. The LDPE, MDPE, and HDPE forms can be classified into polyethylene terephthalate, polyvinyl chloride, polypropylene, polystyrene etc[5]. Various mediums or environment as a whole is used for biodegrading polymers. Due to various physical as well as biological forces depolymerisation can be observed. The physical forces such as temperature, moisture, pressure cause mechanical damage to the polymers[6]. A large number of microorganisms have found to produce enzymes which degrade plastics and many more metallic as well as non metallic compounds.

Today there is a growing interest in the development of biodegradable plastics that would enhance the degradability of other plastic products in landfills and composts under natural conditions [7]. Microbial degradation of plastics is caused by enzymatic activities leading to a chain cleavage of the polymer into oligomers and monomers after which they are further metabolized by the microbial cells. Aerobic metabolism results in carbon dioxide and water[8], whereas anaerobic metabolism results in carbon dioxide, water, and methane as the end products, respectively[9]. One of the major factors in determining the degradability is the melting temperature $(\mathrm{Tm})$.Melting temperature $(\mathrm{Tm})$ is inversely proportional to biodegradability [10]. A large number of parameters such as roughing of surface, formation of holes, cracks, defragmentation, change in color, formation of biofilms, $\mathrm{CO}_{2}$ evolution, oxygen consumption, molar mass, formation of clear zones and weight loss of the compound help in measuring the extent of biodegradability[11,12,13].

This research article evaluates the biodegradability of plastics by Pseudomonas $s p$. isolated by a pure culture shakeflask incubation method. The percent of biodegradation was evaluated by comparing the initial and final dry weights of plastic before and after incubation in their respective culture media. Our hypothesis and purpose of selecting Pseudomonas sp for biodegradation was, this bacteria are predominant in nature and are often found to survive in nutrient deficient ecosystems with their versatile metabolism, hence they would be able to utilize polyethylene amended in the nutrient medium as carbon and energy source when basal nutrients in the medium are exhausted.

It was reported that some bacteria can solubilise many water insoluble minerals like tri-calcium phosphate $[14,15,16]$, manganese dioxide, calcium silicate[17] etc. present in fly-ash[18,19]. Since, Indian fly-ash is full of plant-nutrients, like- $\mathrm{Zn}, \mathrm{Cu}, \mathrm{Ni}, \mathrm{Cr}, \mathrm{V}$ etc.[20,21], so in this paper, an attempt has been made to present the results of some experiments conducted to extract nutrients from the fly-ash using pseudomonas bacteria isolated from waste water so that fly-ash could be effectively utilized in cultivated land for plant-growth

\section{Materials and Methods:- \\ Sample collection:-}

Waste water samples were collected in sterile containers from garbage dump in paper industry, Balichak, Paschimmedinipur (Latitude-22 $2^{\circ} 25^{\prime} 00^{\prime \prime}$ to $22^{\circ} 57^{\prime} 00^{\prime \prime}$ north, longitude- $87^{\circ} 11^{\prime}$ east, altitude 23 meters from mean sea level), West-Bengal, India.

\section{Isolation of plastic degrading micro-organisms:-}

$99 \mathrm{ml}$ of sterile distilled water was taken into a conical flash and One gram of soil sample was added to it and mixed well. Serial dilution of the sample was done. Pour plate method was adopted to isolate the microorganisms, and nutrient agar was used for the culture of bacteria. For each dilution, three replicates were made. For 2-7 days the plates were incubated at $30^{\circ} \mathrm{C}$. Sub-culturing of the developed colonies was done to obtain pure colonies and then the colonies were stored at $40^{\circ} \mathrm{C}$. The developed colonies were isolated and sub cultured repeatedly to get pure colonies and then preserved in slant at $4^{\circ} \mathrm{C}$ [22]. 


\section{Identification of microorganisms:-}

Gram staining, Colony morphology, Biochemical tests( catalase test, gelatin hydrolysis test, indole test, methyl red and voges proskauer test, starch hydrolysis test, and simmon's citrate test), and motility tests were performed on the isolated strains of micro organism.

\section{Selection of plastic:-}

Plastic having 50 microns thickness are used for comparative investigation of their biodegradability nature. The plastic are used to made from a combination of virgin plastic vegetable starch (6\%), organic minerals, and vegetable extracts.

\section{Pre-treatment of plastic:-}

The plastic are cut in small strips and transferred to a fresh solution containing $70 \mathrm{ml}$ Tween $80,10 \mathrm{ml}$ bleach, and $983 \mathrm{ml}$ distilled water and stirring for 30 to 60 minutes [23]. The strips were transferred to a beaker with distilled water and stirred for 1 hour. Further, they were aseptically relocated to ethanol solution 70\% v/v for 30 min. Finally, the plastic strips were transferred to a Petri dish and incubated at 45 to $50^{\circ} \mathrm{C}$ overnight. Ethanol was used to disinfect the plastic and remove any organic matter adhering to its surface.

\section{Plastic degradation by broth culture method:-}

Pre weighed plastic strips were added to the flask containing $50 \mathrm{ml}$ of mineral salt medium and the medium was inoculated with the isolated micro organism. The control flask was maintained with the mineral salt medium containing plastic strips but free of microorganisms. The test and the control samples were left in a shaker at $30^{\circ} \mathrm{C}$ for 1 month period. After the incubation period the strips were collected from the medium, washed with distilled water, dried and weighed. The weight loss in the plastic strips was calculated finally.

\section{Seed Bacterization for Growth Promotion:-}

Seed of Cicer arietinum were bacterized in twice way. For set 1: Seeds of Cicer arietinum were surface-sterilized with $70 \%$ ethanol, $1 \%$ sodium hypochlorite solution and sterilized double-distilled water repeatedly and sequentially up to $5 \mathrm{~min}$. [24] and dried under a sterile air stream. Then seeds were bacterized separately with the selected isolates. $2 \mathrm{ml}$ of bacterial inoculums containing $3 \times 108 \mathrm{CFU} / \mathrm{ml}$ were separately centrifuged at $7000 \mathrm{rpm}$ for $20 \mathrm{~min}$ (Cooling Centrifuge, REMI C-24 BL, India) and supernatant were discarded. Bacterial pallets were washed trice with sterile distilled water and finally suspended with carboxymethyl cellulose solution (1mg CMC in $100 \mathrm{ml}$ sterile distilled water) [25]. Surface-sterilized seeds were then dipped separately in different bacterial solution for 3 hrs. For set 2: Sterilization was done but seeds were not bacterized. 2 seeds form every bacterial solution of set 1 were collected and

kept separately on thermal power-plant ash and general soil. Similarly, 2 seeds of set 2 were kept separately on two week treated thermal power plant ash by those different selected bacteria. After 7,14, 21 and 28 days incubation plant growth-promoting activity was studied.

\section{Results and Discussions:-}

Bacterial strains were isolated from the contaminated waste water sample using Nutrient agar medium respectively. Among this study white bacterial colonies were noted in $10^{5}$ dilution (Figure 1).

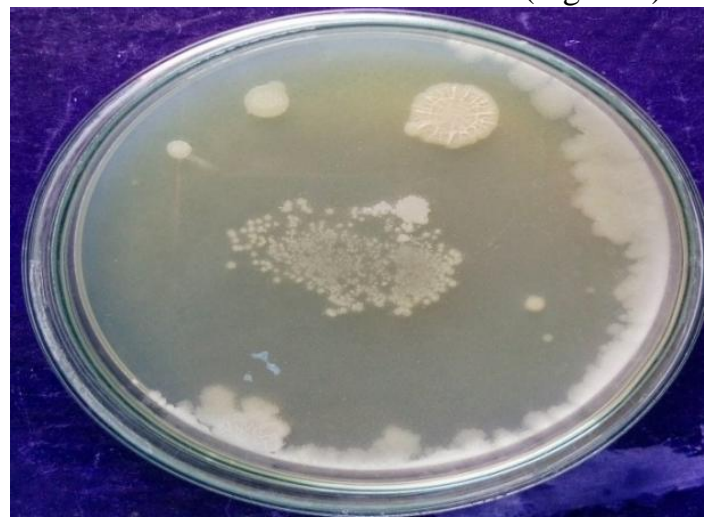

Figure 1:- Isolation of Pseudomonus sp. from waste water of paper mill effluents dump. 
The Pseudomonas sp. from waste water are isolated and characterized on their morphological and biochemical characteristics (Table 1).

Table 1:- Morphological and biochemical characteristics of Pseudomonous sp. isolated from waste water of paper mill effluents dump.

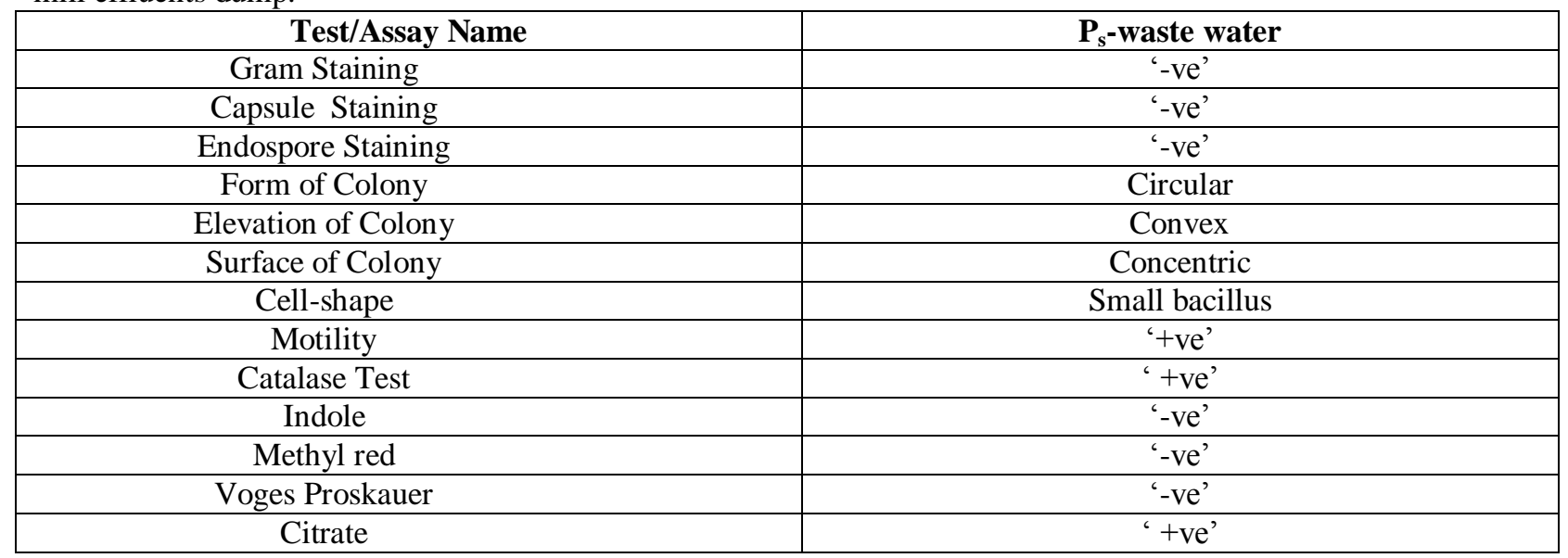

After 4 weeks of incubation in an incubator shaker at $40^{\circ} \mathrm{C}$ and $150 \mathrm{rpm}$, the culture flasks were removed and tested for the viability of bacteria and any contamination in the medium. The blanks and the treatments showed good stability of Pseudomonas in the medium with no sign of contamination. In addition, there was intense bio film formation by all the Pseudomonas sp. which was clearly visible in the broth. From the bellow (Tables 2,3,4,5) and (Figure 2) it can be interpreted that the degradation of plastic strips has taken place. Confirmation of the degradation can be done by observing the weight loss in the plastic strips. By the help of Pseudomonus sp. maximum biodegradation i.e, $45 \%$ was done after 21 days of incubation.

Table 2:-Weight loss determination plastic degradation bacteria after in 7days.

\begin{tabular}{|c|c|c|c|c|}
\hline Organism & Initial weight & Final weight & Weight loss & $\%$ of weight loss \\
\hline Pseudomonas sp. & 0.50 & 0.43 & 0.07 & 14 \\
\hline
\end{tabular}

Table 3:-Weight loss determination plastic degradation bacteria after in 14days.

\begin{tabular}{|c|c|c|c|c|}
\hline Organism & Initial weight & Final weight & Weight loss & $\%$ of weight loss \\
\hline Pseudomonas sp. & 0.43 & 0.38 & 0.05 & 12 \\
\hline
\end{tabular}

Table 4:- Weight loss determination plastic degradation bacteria after in21days.

\begin{tabular}{|c|c|c|c|c|}
\hline Organism & Initial weight & Final weight & Weight loss & $\%$ of weight loss \\
\hline Pseudomonas $s p$. & 0.38 & 0.21 & 0.17 & 45 \\
\hline
\end{tabular}

Table 5:- Weight loss determination plastic degradating bacteria after in28days.

\begin{tabular}{|c|c|c|c|c|}
\hline Organism & Initial weight & Final weight & Weight loss & $\%$ of weight loss \\
\hline Pseudomonas sp. & 0.21 & 0.16 & 0.05 & 24 \\
\hline
\end{tabular}




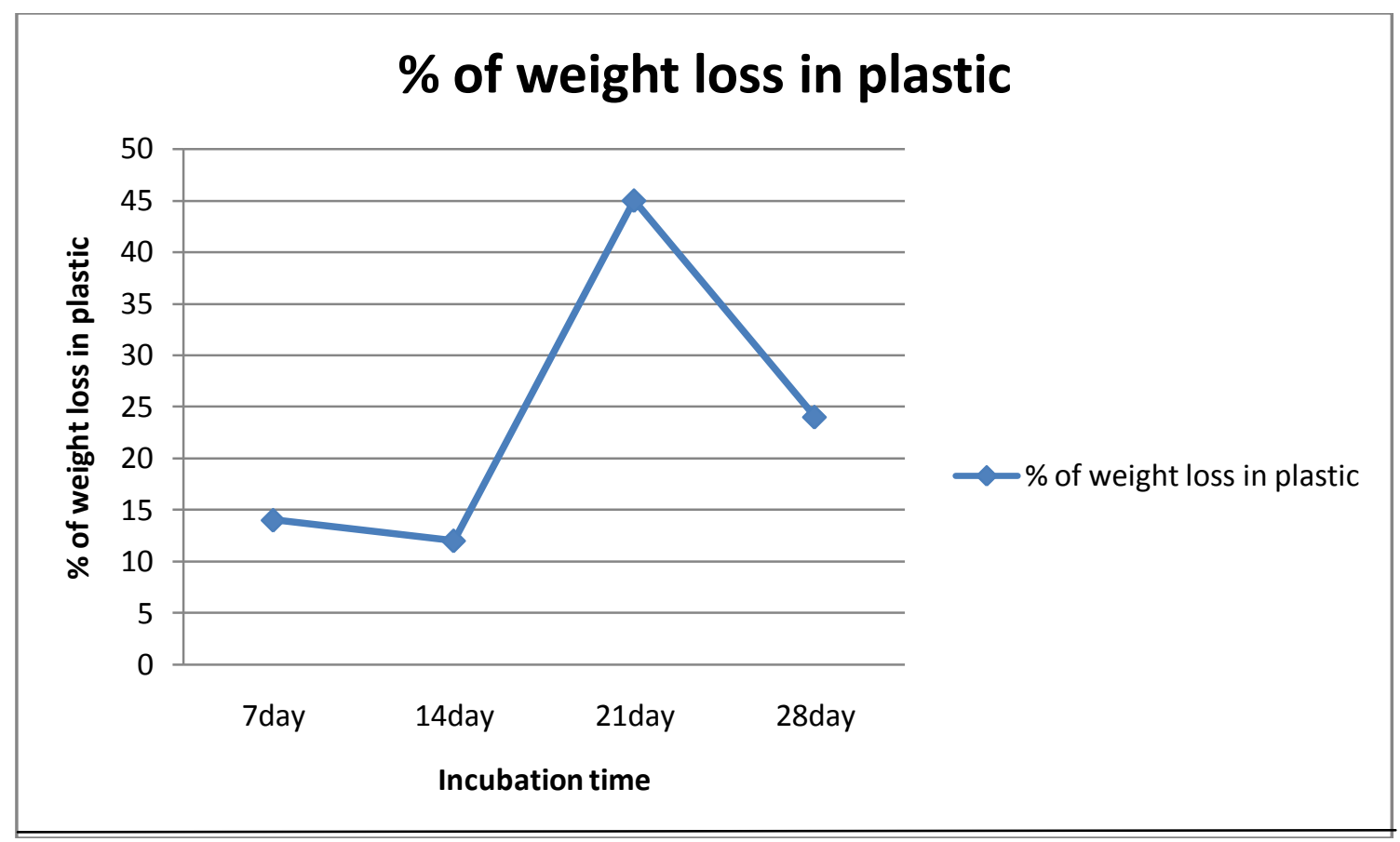

Figure 2:- Trend of biodegradation of plastic by Pseudomonas sp. from waste water.

Plant growth promoting effects and seed germination of plant was carried out on water agar media and fly ash containing soil and the results are shown in the given (Figures 3). After $3^{\text {rd }}$ week the maximum plant growth was occurred. More experimental studies are required to verity the same results for other plants like rabi crop or large plants like mango, jackfruit, guava, banana etc. that can grow on fly-ash and produce flowers and fruits. Other types of cattle-dung can also be used for above experiments. So this is one of the best way to utilize fly-ash to solve the environmental problem.

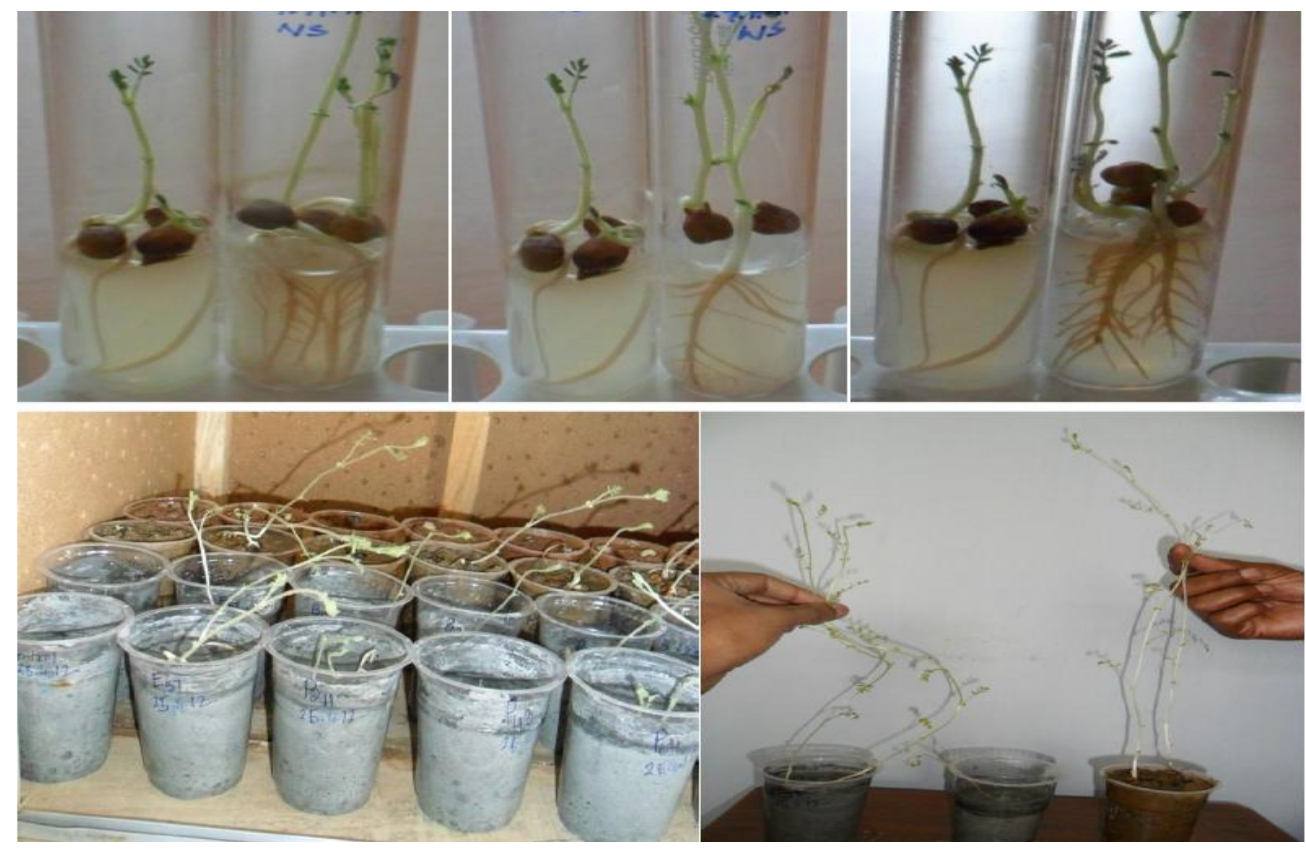

Figure 3:- After $3^{\text {rd }}$ week bacterial isolates plant growth promoting and seed germination on water agar media and fly ash containing soil. 


\section{Conclusion:-}

Biodegradation is a novel procedure to degrade different kinds of artificial substances in a biological manner. This helps to maintain balance in the surrounding. Bacterial strains were successfully isolated from waste water. Isolated bacterial strain are identified as Pseudomonas sp. Most of the plastics are degraded naturally in 2years of decomposition. But LDPE degradation is carried out with microbes to reduce the environmental pollution.

The fly-ash of thermal power plant is a huge source of silica, aluminum, iron and calcium salts, which play as micronutrients for plant growth. Microbes not only play vital role in physical weathering of parental rocks for generation of fertile land or soil but also help in plant nutrition by microbes- plant symbiosis phenomena. Thus, if we apply microbes with fly ash, microbes make ash useful for plants and these plants keep clean the atmosphere. Fly-ash has great potential in agriculture to its efficacy in modification of soil health and crop performance. However, since there is a potential for harming the environment and human health, long term confirmatory research is necessary before planning agriculture as a venue to fly-ash utilization.

\section{Acknowledgments:-}

Authors are thankful to Panskura Banamali College, Karry Mullis Molecular Biology Laboratory (Sponsored by Boost, Government of West-Bengal), India for providing facilities and financial support for the completion of this research work.

\section{References:-}

1. Chand N, Vashishtha SR, "Development, Structure and Strength Properties of PP/PMMA/FA Blends". Bull. Mater. Sci., (2000) 23(2), 103-107.

2. Steveson M, Sagoe-Crentsil K, "Relationship Between Composition, Structure and Strength of Inorganic Polymers, Part 2: Fly Ash-Derived Inorganic Polymers". J. Matter. Sci.,(2005) 40(16), 4247-4259.

3. Paul KT, Satpathy SK, Manna I, Chakroborty KK, Nando GB "Preparation and Characterization of Nano Structured Materials from Fly Ash: A Waste from Thermal Power Stations, by High Energy Ball Milling". Nanoscale Res. Lett.,(2007) 2(8), 397-404.

4. Usha R, Sangeetha T and Palaniswamy M, Libyan Agric Res Center J I nternati (2011)2(4), 200-204.

5. Shimao M. Curr. Opin. Biotechnol ,(2001) 12, 242-247.

6. Bellina G, Tosin M, Degli-Innocenti F. Polym Degrad Stab (2000) 69, 113-120.

7. 7.Pometto, AL; Lee, B; Johnson, KE, Production of an Extracellular Polyethylene- Degrading Enzyme(s) by Streptomyces Species. Appl. Environ. Microbiol,(1992) 58 (2), 731 - 733.

8. Starnecker, A; Menner, M, Assessment of biodegradability of plastics under stimulated composting conditions in a laboratory test system.

9. Int. Biodeterior. Biodegrad(1996), 85 - 92.

10. Gu, JD; Ford, TE; Mitton, DB; Mitchell, R (2000). Microbial corrosion of metals. The Uhlig Corrosion Handbook. 2nd Edition. Wiley, New York, USA.

11. Wang YZ, Yang KK, Wang XL, Zhou Q, Zheng CY, Chen ZF.J Poly Environ,(2004)12, 7-11.

12. Sharma Prabhat, Bhattacharyya S, Verma Vishal, Kalyani RK, Kumar Vijai, Pandey KN and Singh M. Internat Res J Environ Sciences, (2013)2(9), 83-85.

13. Premraj R,Dan Mukesh Doble. Ind J Biotech, (2005) 4,186-193.

14. Priyanka N. Internation J of Biomed Ad Res,( 2011)2(9), 235-238.

15. Khan AA, Jilani G, Akhtar MS, Naqvi SMS, Rasheed M , "Phosphorus Solubilizing Bacteria: Occurrence, Mechanisms and Their Role in Crop Production". J. Agric. Boil. Sci, (2009) 1,48-58.

16. Mahdi SS, Hassan GI, Hussain A, Rasool F (2011). "Phosphorus Availability Issue- Its Fixation and Role of Phosphate Solubilizing Bacteria in Phosphate Solubilization”. Res. J. Agric. Sci, (2011) 2, 174-179.

17. King EO, Ward MK, Raney DE, "Two Simple Media for the Demonstration of Pyocyanin and Fluorescein". $J$. Lab. and Clinical Microbiol,(1954) 44, 301-307.

18. Bennett PC, Rogers JR, Choi WJ, "Silicates, Silicate Weathering, and Microbial Ecology". Geomicrobiology Journal,(2001) 18 , 3-19.

19. Giere R, Carleton LE, Lumpkin GR , "Micro- and Nano-Chemistry of Fly Ash from Coal-Fired Power Plant". Am. Mineral,(2003) 88,1853.

20. Sadasivan S, Negi BS, "Chemical Characteristics of Fly Ash from Coal Fired Thermal Power Plants in India", Science of the Total Environment, (1991)103,151-158. 
21. Khandkar UR, Gangwar MS, Srivastava PC, Singh M (1993). "Edaphological Characteristics of Unwealthered and Welathered Fly Ashes from Gondwana and Lignite Coal", Environment Pollution.

22. Jayaprakashvel M, Muthezhilan R, Srinivasan R, Hussain AJ, Gobalakrishnan S, Bhagat J, Kaarthikeyan C and Muthulakshmi R, "Hydrogen Cyanide Mediated Biocontrol Potential of Pseudomonas sp". AMET1055 Isolated from the Rhizosphere of Coastal Sand Dune Vegetation, (2010)10, 39-42.

23. Nishida H, Tokiwa Y. J Environ Polym Degrad, (1998)1, 227-233.

24. El-Shafei, HA; El-Nasser, NHA; Kansoh, AL; Ali, AM, Biodegradation of disposable polyethylene by fungi and Streptomyces species. Polym. Degrad. Stab,(1998) 62, 361 - 365.

25. Abdul Baki A A, Anederson J D , "Vigour Derermination in Soybean Seed by Multiple Criteria". Crop Sci,(1973) 13, 630-633.

26. Holt JG, Krieg NR, Sneath PHA, Staley JT, Williams ST (1994). "Bergey's Manual of Determinative Bacteriology", 9th Edition Published by Williams and Wilkins, A. Wavely Company, Baltimore. 